\title{
HUBUNGAN PENGETAHUAN WANITA USIA SUBUR TENTANG KANKER SERVIKS DENGAN MINAT MELAKUKAN PAP SMEAR DI RT 16 KELURAHAN BLABAK KECAMATAN PESANTREN KOTA KEDIRI.
}

Lely Khulafa'ur Rosidah ${ }^{1}$, Kiky Kusuma Ningrum ${ }^{2}$

1,2 Akademi Kebidanan Dharma Husada Kediri Jawa Timur

Kanker serviks adalah kanker pembunuh perempuan Indonesia no.1 tertinggi saat ini. Di Asia Tenggara terdapat 40.000 kasus baru kanker serviks dengan sekitar 22.000 kematian. Data DINKES kota Kediri (2015), penderita kanker serviks mencapai 100-120 pertahun. Karena tingginya angka kematian akibat kanker serviks maka perlu adanya deteksi dini. Penelitian ini bertujuan untuk mengetahui hubungan pengetahuan wanita usia subur dengan minat melakukan Pap smear.

Desain penelitian yang digunakan analitik korelasional dengan pendekatan cross sectional. Populasi penelitian ini adalah semua wanita usia subur berjumlah 30 orang. Teknik sampling yang digunakan total sampling maka sampelnya yaitu seluruh wanita usia subur sebanyak 30 orang. Variabel yang digunakan variabel Independen yaitu pengetahuan wanita usia subur tentang kanker serviks sedangkan variabel dependen yaitu minat melakukan pap smear. Lokasi penelitian di RT 16 Kelurahan Blabak Kecamatan Pesantren Kota Kediri pada tanggal 2-16 Mei 2017. Pengumpulan data menggunakan kuesioner, kemudian data diolah dengan proses editing, coding, scoring, tabulating, selanjutnya dianalisa dengan spearman rank.

Hasil penelitian dari 30 responden didapatkan berpengetahuan baik dengan minat tinggi 25 responden $(83,3 \%)$, berpengetahuan cukup dengan minat sedang 5 responden $(16,7 \%)$, berpengetahuan rendah dengan minat rendah 0 responden (0). Dari perhitungan uji spearmank rank menunjukkan hasil koefisien sebesar 0,668 dengan taraf signifikansi sebesar 0,000 maka H1 diterima.

Berdasarkan hasil penelitian dapat disimpulkan bahwa ada hubungan pengetahuan wanita usia subur tentang kanker serviks dengan minat melakukan Pap smear. Dalam meningkatkan pengetahuan responden tentang kanker serviks dengan pemeriksaan Pap smear perlu adanya peranan aktif dari petugas kesehatan untuk memberikan penyuluhan.

Kata kunci : Pengetahuan, Wanita Usia Subur, Kanker Serviks, Minat, Pap Smear

Korespondensi: Jl. Teratai RT 20 RW 03 Kel.Ngampel Kec.Mojoroto Kota Kediri Hp.085664425144 E-mail: iffat.yakta@gmail.com 


\section{PENDAHULUAN}

Kanker serviks adalah pertumbuhan selsel abnormal pada serviks di mana sel-sel normal berubah menjadi sel kanker. Banyak faktor resiko yang menyebabkan kanker serviks. Jika pertumbuhannya tidak dihentikan maka pertumbuhannya akan terus berlanjut secara perlahan-lahan. Apabila sel kanker telah menyerang satu atau sekelompok sel maka perkembangannya akan menjadi sangat cepat dan secara terus menerus. Dan kanker serviks itu sendiri tidak memperlihatkan tandatanda awal yang jelas, tetapi bisa disembuhkan bila ditemukan secara dini dengan melakukan screening atau melakukan pemeriksaan tanpa menunggu keluhan.

Di Indonesia, kanker serviks adalah kanker pembunuh perempuan Indonesia no. 1 tertinggi saat ini (Purwoastuti dan Walyani, 2015 : 137). Kurangnya pengetahuan masyarakat mengenai kanker serviks dan keengganan untuk melakukan deteksi dini menyebabkan lebih dari 70\% mulai menjalani perawatan medis justru ketika sudah berada kondisi parah dan sulit disembuhkan. Hanya sekitar $2 \%$ dari perempuan Indonesia mengetahui kanker serviks (Sabrina, 2009 : 78).

Menurut WHO tahun 2010, kanker serviks merupakan kanker nomor dua terbanyak pada perempuan berusia 15-45 tahun setelah kanker payudara. Setiap tahun sekitar 470.000 wanita di seluruh dunia didiagnosis kanker serviks 230.000 meninggal karena penyakit ini dan lebih dari 190.000 diantaranya berasal dari Negara-negara berkembang (Samadi, 2011).

Di Asia Tenggara terdapat 40.000 kasus baru kanker serviks dengan sekitar 22.000 kematian (Samadi, 2011). Insiden kanker serviks menurut perkiraan DEPKES, 100 per 100.000 penduduk pertahun, sedangkan dari data Laboratorium Patologi Anatomi seluruh Indonesia, frekuensi kanker serviks paling tinggi diantara kanker yang ada di Indonesia, bila dilihat penyebarannya terlihat bahwa 92,4\% terakumulasi di Jawa dan Bali (Romauli dan Vindari, 2012 : 152).

Propinsi Jawa Timur merupakan salah satu propinsi penyumbang terbesar jumlah kasus kanker serviks di Indonesia. Di propinsi Jawa Timur, prevelensi jumlah kanker serviks sebesar 21.313 penduduk (Pusdatin, 2015). Menurut data dinas kesehatan kota Kediri (2015), penderita kanker serviks mencapai 100-120 pertahun.

Seperti penyakit kanker pada umumnya, kanker serviks akan menimbulkan masalah pada kesakitan, penderitaan, kematian finansial dan ekonomi, masalah pada pemerintah. Dengan demikian penanggulangan kanker serviks harus dilakukan secara menyeluruh dan terintegrasi (Romauli dan Vindari, 2012 : 152). Lebih dari 95\% kanker serviks berkaitan erat dengan infeksi Human Papiloma Virus (HPV) yang dapat ditularkan melalui aktivitas seksual (Romauli dan Vindari, 2012 : 152).

Layaknya semua kanker, kanker leher rahim terjadi ditandai dengan adanya pertumbuhan sel-sel pada rahim yang tidak lazim (abnormal). Tetapi sebelum sel-sel tersebut menjadi sel-sel kanker, terjadi beberapa perubahan yang dialami oleh sel-sel tersebut. Perubahan sel-sel tersebut biasanya memakan waktu sampai bertahun-tahun sebelum sel-sel tadi berubah menjadi sel-sel kanker. Selama jeda tersebut, pengobatan yang tepat akan segera dapat menghentikan sel-sel yang abnormal tersebut sebelum berubah menjadi sel kanker (Purwoastuti dan Walyani, 2015 : 137-138). Sel-sel yang abnormal tersebut dapat dideteksi kehadirannya dengan suatu test yang disebut"Pap Smear Test", sehingga semakin dini sel-sel abnormal tadi terdeteksi, semakin rendahlah risiko seseorang menderita kanker leher rahim (Purwoastuti dan Walyani, 2015 : 138).

Pap smear test adalah suatu test yang aman dan murah dan telah dipakai bertahuntahun lamanya untuk mendeteksi kelainankelainan yang terjadi pada sel-sel leher rahim (Proverawati dan Misaroh, 2009 : 122). Pap Smear adalah sebuah metode pemeriksaan cairan lender serviks (Handayani, 2012 :14). Uji pap telah terbukti dapat menurunkan kejadian karsinoma serviks yang ditemukan stadium prakanker, ceoplasia, intraepitel (Romauli dan Vindari, 2012 :156).

Namun, kesadaran masyarakat untuk memeriksakan diri sejak dini dirasakan sangat rendah. Selain itu, masyarakat merasa pemeriksaan pap smear dianggap tabu, ibu merasa malu untuk melakukan pemeriksaan. 
Indikasinya adalah lebih dari $70 \%$ penderita yang datang ke Rumah Sakit sudah pada stadium lanjut. Seluruh masyarakat seharusnya terlibat dalam upaya program pencegahan terhadap kanker serviks. Program screening (deteksi dini) seharusnya menjadi upaya pencegahan yang ditunjukkan untuk wanita Indonesia (Novel, 2010).

Biasanya penderita datang ke dokter kebidanan dan kandungan sudah terlambat sehingga pengobatan yang dapat diusahakan hanyalah perawatan. Dilakukan dengan tujuan peningkatan kualitas hidupnya. Banyak hal yang membuat penderita yang datang terlambat antara lain kurangnya pengetahuan dan pengertian tentang penyakit kanker pada umumnya. Hal inilah yang menyebabkan angka kematian sangat tinggi. Maka program dinas kesehatan melalui puskesmas saat ini diharapkan dapat menekankan pada upaya pencegahan terhadap penyakit-penyakit berbahaya seperti kanker serviks. Sehingga penting dilakukan sosialisasi dan skrining terhadap penyakit ini. Dengan mengadakan pemeriksaan pap smear gratis di puskesmas, penyakit kanker serviks dapat di deteksi secara dini. Dengan begitu pengobatan akan lebih mudah dilakukan.

Oleh karena itu, pemeriksaan rutin pap smear wajib dilakukan minimal sekali setiap tahun bagi wanita yang sudah pernah melakukan hubungan seksual. Biaya yang dikeluarkan untuk pap smear maupun biaya pengobatan untuk stadium pra-kanker juga akan lebih murah dibandingkan dengan biaya untuk penyembuhan kanker yang sudah tergolong invasif (Handayani, $2012: 30$ ). Pap smear dilakukkan saat tidak haid dan 24 jam sebelumnya tidak melakukan hubungan seksual (Handayani, $2012: 31$ ).

Berdasarkan studi pendahuluan yang dilakukan peneliti pada tanggal 20 Februari 2017 di RT 16 Kelurahan Blabak, dari 10 orang wanita usia subur yang diwawancara didapatkan 2 orang $(20 \%)$ ibu sudah mengetahui dan mengerti tentang kanker serviks dan sisanya 8 orang $(80 \%)$ wanita usia subur belum mengetahui dan mengerti tentang kanker serviks. Dari 10 orang wanita usia subur yang diwawancara tersebut juga didapatkan 2 orang $(20 \%)$ sudah melakukan pap smear dan sisanya 8 orang $(80 \%)$ belum melakukan pap smear. Wanita usia subur yang belum pernah melakukan pap smear 6 orang $(60 \%)$ beralasan takut dan malu dan sisanya 4 orang $(40 \%)$ beralasan malas datang ke tempat pelayanan kesehatan. Sehingga perlu diberikan motivasi dan penyuluhan tentang pentingnya pemeriksaan pap smear.

Berdasarkan uraian diatas maka peneliti tertarik untuk mengadakan penelitian yang berjudul "Hubungan Pengetahuan Wanita Usia Subur Tentang Kanker Serviks Dengan Minat Melakukan Pap Smear di RT 16 Kelurahan Blabak Kecamatan Pesantren Kota Kediri”.

\section{METODE PENELITIAN}

Desain penelitian yang digunakan analitik korelasional dengan pendekatan cross sectional. Populasi penelitian ini adalah semua wanita usia subur berjumlah 30 orang di RT 16 Kelurahan Blabak Kecamatan Pesantren Kota Kediri. Teknik sampling yang digunakan total sampling maka sampelnya yaitu seluruh wanita usia subur di RT 16 Kelurahan Blabak Kecamatan Pesantren Kota Kediri sebanyak 30 orang. Variabel yang digunakan variabel Independen yaitu pengetahuan wanita usia subur tentang kanker serviks sedangkan variabel dependen yaitu minat melakukan pap smear.

Instrumen yang digunakan pada penelitian ini adalah kuesioner. Uji statistik yang digunakan dalam penelitian ini adalah teknik Spearman Rank.

\section{HASIL}

Pengetahuan Wanita Usia Subur Tentang Kanker Serviks 
Tabel IV.6 Distribusi Frekuensi Pengetahuan Wanita Usia Subur Tentang Kanker Serviks di RT 16 Kelurahan Blabak Kecamatan Pesantren Kota Kediri

\begin{tabular}{ccccc} 
No & & Pengetahuan & Frekuensi & Prosentase (\%) \\
\hline 1 & Baik & & 13 & 43,33 \\
\hline 2 & Cukup & & 11 & 36,67 \\
\hline 3 & Kurang & & 6 & 20 \\
\hline & & Total & 30 & 100
\end{tabular}

Berdasarkan hasil tabulasi pada tabel IV. 6 diketahui dari 30 responden di atas bahwa frekuensi tertinggi adalah responden yang mempunyai pengetahuan baik adalah 13

Tabel IV.7 Distribusi Frekuensi Pengetahuan Wanita Usia Subur Tentang Kanker Serviks berdasarkan indicator di RT 16 Kelurahan Blabak Kecamatan Pesantren Kota Kediri

\begin{tabular}{|c|c|c|c|c|c|c|c|c|c|}
\hline \multirow{3}{*}{ No. } & \multirow{3}{*}{$\begin{array}{l}\text { Pengetahuan Tentang } \\
\text { Kanker Serviks }\end{array}$} & \multicolumn{6}{|c|}{ Kriteria pengetahuan } & \multirow{2}{*}{\multicolumn{2}{|c|}{ Total }} \\
\hline & & \multicolumn{2}{|c|}{ Baik } & \multicolumn{2}{|c|}{ Cukup } & \multicolumn{2}{|c|}{ Kurang } & & \\
\hline & & $\mathbf{F}$ & $\%$ & $\mathbf{F}$ & $\%$ & $\mathbf{F}$ & $\%$ & $\mathbf{F}$ & $\%$ \\
\hline 1 & Pengertian & 18 & 60.0 & 8 & 26.7 & 4 & 13.3 & 30 & 100 \\
\hline 2 & $\begin{array}{l}\text { Faktor-faktor yang } \\
\text { mempengaruhi }\end{array}$ & 19 & 63.3 & 8 & 26.7 & 3 & 10.0 & 30 & 100 \\
\hline 3 & Tanda dan gejala & 8 & 26.7 & 15 & 50.0 & 7 & 23.3 & 30 & 100 \\
\hline 4 & Pencegahan & 4 & 13,3 & 20 & 66,7 & 6 & 20,0 & 30 & 100 \\
\hline 5 & Stadium & 10 & 33,3 & 8 & 26,7 & 12 & 40,0 & 30 & 100 \\
\hline 6 & Pengobatan & 5 & 16,7 & 16 & 53,3 & 9 & 30,0 & 30 & 100 \\
\hline
\end{tabular}

Berdasarkan hasil tabulasi pada tabel IV.7 diketahui dari 30 responden di atas bahwa frekuensi tertinggi adalah responden yang mempunyai pengetahuan cukup dengan indicator pencegahan adalah 20 responden

responden $(43,33 \%)$ dan frekuensi terendah adalah responden yang mempunyai pengetahuan kurang 6 responden $(20 \%)$.

Tabel 8 Distribusi Frekuensi Minat Wanita Usia Subur Melakukan Pap Smear di RT 16 Kelurahan Blabak Kecamatan Pesantren Kota Kediri

\begin{tabular}{|c|c|c|c|}
\hline No & Minat & Frekuensi & Prosentase $(\%)$ \\
\hline 1 & Tinggi & 26 & 86,67 \\
\hline 2 & Sedang & 4 & 13,33 \\
\hline 3 & Rendah & 0 & 0 \\
\hline
\end{tabular}

Berdasarkan hasil tabulasi pada tabel IV.8 diketahui dari 30 responden di atas bahwa frekuensi tertinggi adalah responden yang mempunyai minat tinggi yaitu 26 responden
$(66,7 \%)$ dan frekuensi terendah adalah responden yang mempunyai pengetahuan kurang dengan indicator faktor-faktor yang mempengaruhi adalah 3 responden $(10,0 \%)$.

Tabel .9 Distribusi Frekuensi Minat Wanita Usia Subur Melakukan Pap Smear Berdasarkan Indikator di RT 16 Kelurahan Blabak Kecamatan Pesantren Kota Kediri 


\begin{tabular}{|c|c|c|c|c|c|c|c|c|c|}
\hline \multirow{3}{*}{ No. } & \multirow{3}{*}{ Indikator minat } & \multicolumn{6}{|c|}{ Kriteria minat } & \multirow{2}{*}{\multicolumn{2}{|c|}{ Total }} \\
\hline & & \multicolumn{2}{|c|}{ Tinggi } & \multicolumn{2}{|c|}{ Sedang } & \multicolumn{2}{|c|}{ Rendah } & & \\
\hline & & $\mathbf{F}$ & $\%$ & $\mathbf{F}$ & $\%$ & $\mathbf{F}$ & $\%$ & $\mathbf{F}$ & $\%$ \\
\hline 1 & Ketertarikan & 22 & 73,3 & 8 & 26,7 & 0 & 0 & 30 & 100 \\
\hline 2 & Perhatian & 24 & 80,0 & 6 & 20,0 & 0 & 0 & 30 & 100 \\
\hline 3 & Motivasi & 23 & 76,7 & 6 & 20,0 & 1 & 3,3 & 30 & 100 \\
\hline 4 & Pengetahuan & 12 & 40,0 & 17 & 56,7 & 1 & 3,3 & 30 & 100 \\
\hline
\end{tabular}

Berdasarkan hasil tabulasi pada tabel IV.9 diketahui dari 30 responden di atas bahwa frekuensi tertinggi adalah responden yang mempunyai minat tinggi dengan indicator perhatian adalah 24 responden $(80,0 \%)$ dan frekuensi terendah adalah responden yang mempunyai minat rendah dengan indicator motivasi dan pengetahuan adalah 1 responden $(3,3 \%)$.

Tabel .10 Tabel Silang dengan Hubungan Pengetahuan Wanita Usia Subur Dengan Minat Melakukan Pap Smear di RT 16 Kelurahan Blabak Kecamatan Pesantren Kota Kediri

\begin{tabular}{cccccccccc} 
& & \multicolumn{9}{c}{ Pengetahuan } & \multicolumn{2}{c}{ Total } \\
\cline { 3 - 10 } No. & Minat & \multicolumn{2}{c}{ Baik } & \multicolumn{2}{c}{ Cukup } & \multicolumn{2}{c}{ Kurang } & \multicolumn{2}{c}{} \\
\cline { 3 - 10 } & & $\mathbf{F}$ & $\mathbf{\%}$ & $\mathbf{F}$ & $\mathbf{\%}$ & $\mathbf{F}$ & $\mathbf{\%}$ & $\mathbf{F}$ & $\mathbf{\%}$ \\
\hline 1 & Tinggi & 13 & 43.3 & 11 & 36.7 & 1 & 3.3 & 25 & 83,3 \\
\hline 2 & Sedang & 0 & 0 & 0 & 0 & 5 & 16,7 & 5 & 16,7 \\
\hline 3 & Rendah & 0 & 0 & 0 & 0 & 0 & 0 & 0 & 0 \\
\hline & Total & 13 & 43,3 & 11 & 36,7 & 6 & 20,0 & 30 & 100
\end{tabular}

Berdasarkan hasil tabulasi pada tabel IV. 10 diketahui dari 30 responden yaitu :

a. Minat tinggi dengan pengetahuan baik sebanyak 13 responden $(43,3 \%)$, dan minat tinggi dengan pengetahuan cukup sebanyak 11 responden $(36,7 \%)$, dan minat tinggi dengan pengetahuan kurang sebanyak 1 responden $(3,3 \%)$.

b. Minat sedang dengan pengetahuan baik sebanyak 0 responden $(0 \%)$, dan minat sedang dengan pengetahuan cukup sebanyak 0 responden $(0 \%)$, dan minat sedang dengan pengetahuan kurang sebanyak 5 responden $(16,7 \%)$.

\section{PEMBAHASAN}

Pengetahuan Wanita Usia Subur tentang Kanker Serviks

Berdasarkan tabel IV. 6 dari hasil penelitian yang di laksanakan pada tanggal 2- c. Minat rendah dengan pengetahuan baik sebanyak 0 responden $(0 \%)$, dan minat rendah dengan pengetahuan cukup sebanyak 0 responden $(0 \%)$, dan minat rendah dengan pengetahuan kurang sebanyak 0 responden $(0 \%)$.

16 Mei 2017 di RT 16 Kelurahan Blabak Kecamatan Pesantren Kota Kediri diketahui dari 30 responden di atas bahwa frekuensi tertinggi adalah responden yang mempunyai pengetahuan baik 13 responden $(43,33 \%)$ dan frekuensi terendah adalah responden yang mempunyai pengetahuan kurang adalah 6 responden $(20 \%)$.

Dalam buku karangan Notoatmodjo (2003) menyebutkan bahwa pengetahuan 
adalah merupakan hasil "tahu" dan ini terjadi setelah orang mengadakan penginderaan terhadap suatu objek tertentu. Penginderaan terhadap objek terjadi melalui panca indra manusia yakni penglihatan, pendengaran, penciuman, rasa, dan raba dengan sendiri. Pada waktu penginderaan sampai menghasilkan pengetahuan tersebut sangat dipengaruhi oleh intensitas perhatian persepsi terhadap objek. Sebagian besar pengetahuan manusia diperoleh melalui mata dan telinga (Wawan \& Dewi, 2010:11).

Pengetahuan yang baik itu maka tetap untuk dipertahankan dan wanita usia subur itu lebih menambah lagi wawasan dan pengetahuan-pengetahuan yang lebih banyak lagi agar pengetahuannya tentang kanker serviks lebih meluas dan mendalam.

Pencegahan itu ada beberapa yaitu pencegahan primer, pencegahan sekunder, hindari merokok, melakukan vaksinasi, rutin melakukan deteksi dini dengan pap smear, deteksi dini dengan IVA (Handayani, 2012: 28-31).

Pengetahuan tentang kanker serviks merupakan faktor penting yang harus diberikan atau disampaikan kepada wanita usia subur dengan cara mengadakan penyuluhanpenyuluhan, di tempat PKK, atau dipertemuan yang dilakukan oleh bidan atau tenaga kesehatan lainnya. Salah satu faktor yang mempengaruhi pengetahuan cukup dengan indicator pencegahan pada wanita usia subur tentang kanker serviks adalah informasi tentang kanker serviks. Berdasarkan tabel IV. 4 ada 4 responden $(13,33 \%)$ tidak pernah mendapat informasi tentang kanker serviks.

Pada dasarnya pengetahuan akan terus bertambah dan bervariatif sesuai dengan proses pengalaman manusia yang dialami. Menurut Brunner, proses pengetahuan tersebut melibatkan tiga aspek, yaitu informasi, proses transformasi, dan proses evaluasi. Informasi baru yang didapat merupakan pengganti pengetahuan yang telah diperoleh sebelumnya atau merupakan penyempurnaan informasi sebelumnya (Wahit Iqbal, 2011: 81).

Pernah atau belumnya mendapatkan informasi merupakan faktor yang mempengaruhi pengetahuan wanita usia subur tentang kanker serviks. informasi tersebut bisa diperoleh dari sumber-sumber seperti Orang tua, Teman/saudara, Tenaga Kesehatan, maupun Media Massa.

Semakin banyak informasi yang didapat maka semakin bertambah pula pengetahuannya. Seorang wanita usia subur yang tidak pernah mendapat informasi atau pengetahuan tentang kanker serviks tentu beda dengan wanita usia subur yang sudah mengerti, pengetahuannya akan lebih banyak dan lebih memahami tentang apa itu kanker

Selain dipengaruhi oleh informasi, faktor yang mempengaruhi pengetahuan lainnya adalah tingkat pendidikan. Berdasarkan tabel IV. 2 dari 30 responden diatas diketahui bahwa frekuensi tertingi pada karakteristik responden berdasarkan pendidikan terakhir adalah responden dengan tingkat pendidikan SMA, yaitu sebanyak 13 responden (43,33\%).

Faktor-faktor yang mempengaruhi pengetahuan diantaranya terdiri dari pendidikan, pekerjaan dan umur. Akan tetapi perlu ditekankan, bukan berarti seseorang yang berpendidikan rendah muthlak berpengetahuan rendah pula. Hal ini mengingat bahwa peningkatan pengetahuan tidak muthlak diperoleh dari pendidikan formal saja, akan tetapi dapat diperoleh melalui pendidikan non formal (Wawan \& Dewi, 2010 : 16).

Berdasarkan fakta diatas mayoritas wanita usia subur diwilayah tersebut adalah berpendidikan terakhir SMA. Maka pengetahuan yang mereka dapat masih kurang belum begitu meluas. Namun, meskipun mayoritas masih berpendidikan SMA, tidak menutup kemungkinan jika mereka sudah mendapat informasi yang cukup. Tetapi sebagian dari mereka sudah mengetahui tentang kanker serviks.

Jika seseorang memiliki pengalaman dan pendidikan yang luas, maka pengetahuan yang didapat juga semakin bertambah. Maka dari itu sangatlah perlu pendidikan atau pengetahuan tentang kanker serviks bagi para wanita usia subur. Pendidikan yang tinggi akan berpengaruh pada penerimaan hal-hal baru dan dapat menyesuaikan diri dengan hal baru.

Menurut Thomas yang dikutip oleh Nursalam (2003), pekerjaan adalah keburukan yang harus dilakukan terutama untuk menunjang kehidupannya dan kehidupan keluarga. Pekerjaan bukanlah sumber 
kesenangan, tetapi lebih banyak merupakan cara mencari nafkah yang membosankan, berulang dan banyak tantangan. Sedangkan bekerja umumnya merupakan kegiatan yang menyita waktu (Wawan \& Dewi, 2010 : 16).

Pekerjaan sebagai ibu rumah tangga sangat menyita waktu pada wanita usia subur sehingga kesempatan untuk mendapatkan informasi tentang kanker serviks juga kurang sehingga berpengaruh terhadap pengetahuan mereka.

Pengetahuan wanita usia subur tentang masalah kesehatan sebenarnya bisa ditingkatkan bila ada peranan aktif dari petugas tenaga kesehatan untuk memberikan informasi atau mengadakan penyuluhan tentang kanker serviks serta partisipasi dari wanita usia subur untuk memghadiri atau mrngikuti acara tersebut.

Berdasarkan fakta diatas dapat disimpulkan bahwa tampak sebagian besar responden memiliki pengetahuan cukup tentang kanker serviks, dan dalam penelitian ini ditinjau dari segi informasi ada responden yang tidak pernah mendapat informasi tentang apa itu kanker serviks. Sehingga dalam hal ini menunjukkan bahwa pengetahuan wanita usia subur yang sebagian besar pekerjaannya sebagai ibu rumah tangga (IRT) akan pengetahuannya tentang kanker serviks masih cenderung cukup.

\section{Minat Melakukan Pap Smear}

Berdasarkan tabel IV. 7 dari hasil penelitian yang di laksanakan pada tanggal 216 Mei 2017 di RT 16 Kelurahan Blabak Kecamatan Pesantren Kota Kediri diketahui dari 30 responden di atas bahwa frekuensi tertinggi adalah responden yang mempunyai minat tinggi adalah 26 responden $(86,67 \%)$ dan frekuensi terendah adalah responden yang mempunyai minat sedang adalah 4 responden $(13,33 \%)$.

Berdasarkan tabel IV. 7 dari hasil penelitian yang di laksanakan pada tanggal 216 Mei 2017 di RT 16 Kelurahan Blabak Kecamatan Pesantren Kota Kediri diketahui dari 30 responden di atas bahwa frekuensi tertinggi adalah responden yang mempunyai minat tinggi dengan indikator perhatian adalah 24 responden $(80,0 \%)$ dan frekuensi terendah adalah responden yang mempunyai minat rendah dengan indikator motivasi dan pengetahuan adalah 1 responden $(3,3 \%)$.

Minat adalah suatu rasa lebih suka dan rasa ketertarikan pada suatu hal atau aktivitas, tanpa ada yang menyuruh. Minat pada dasarnya adalah penerimaan akan suatu hubungan antara diri sendiri dengan sesuatu di luar diri. Semakin kuat atau dekat hubungan tersebut, semakin besar minat (Slameto, 2010 : 180).

Mempertahankan minat yang tinggi dan bagi wanita usia subur yang minatnya rendah maka perlu untuk ditingkatkan dan menambah wawasan lalu mengikuti acara penyuluhanpenyuluhan, PKK yang telah diadakan oleh bidan maupun tenaga kesehatan lainnya.

Faktor yang mempengaruhi minat adalah tingkat pendidikan. Berdasarkan tabel IV. 2 dari 30 responden diatas diketahui bahwa frekuensi tertingi pada karakteristik responden berdasarkan pendidikan terakhir adalah responden dengan tingkat pendidikan SMA, yaitu sebanyak 13 responden (43,33\%).

Semakin tinggi dan semakin formal tingkat pendidikan yang dimiliki seseorang maka semakin besar pula kegiatan bersifat intelek yang dilakukan L.W. Green mengatakan bahwa "jika ada seseorang yang mempunyai pengetahuan baik, maka ia mencari pelayanan yang kompeten atau lebih aman baginya" (Wordpress, 2010).

Berdasarkan fakta diatas mayoritas wanita usia subur diwilayah tersebut adalah berpendidikan terakhir SMA. Sehingga pengalaman yang banyak maka akan berpengaruh juga pada dirinya maka dari itu minat wanita usia subur tersebut tinggi untuk melakukan pap smear.

Pengetahuan tentang pap smear merupakan faktor penting yang harus diberikan kepada wanita usia subur dengan cara mengadakan penyuluhan yang dilakukan oleh bidan atau tenaga kesehatan lainnya. Kurangnya pengetahuan maka wanita usia subur tersebut tidak akan tahu pentingnya untuk melakukan pap smear dan tidak ada minat untuk melakukan pap smear.

Berdasarkan tabel IV. 7 dari 30 responden dengan frekuensi tertinggi yaitu yang mempunyai minat tinggi dengan indicator motivasi sebanyak 23 responden (76,7\%).

Motivasi merupakan suatu usaha atau pendorong yang dilakukan secara sadar untuk 
melakukan suatu tindakan lain mewujudkan perilaku yang tearah demi pencapaian tujuan yang diharapkan dalam situasi interaksi (Supriatna, 2009).

Wanita usia subur tersebut termotivasi oleh keluarga, suami maupun temannya akan pentingnya melakukan pap smear dan wanita usia subur itu cukup memperoleh informasi tentang pap smear.

\section{Hubungan Pengetahuan Wanita Usia Subur tentang Kanker Serviks dengan Minat Melakukan Pap Smear}

Dari hasil tabulasi silang dapat disimpulkan bahwa frekuensi tertinggi adalah responden yang memiliki pengetahuan baik dan minat tinggi 13 responden $(43,3 \%)$ sedangkan frekuensi terendah dimiliki oleh responden yang memiliki pengetahuan kurang dan minat sedang 1 responden $(3,3)$.

Berdasarkan hasil perhitungan korelasi seperti yang tertera pada lampiran 16 Dari perhitungan statistik dengan menggunakan uji statistik Spearman Rank menunjukkan hasil koefisien korelasi sebesar 0,668 dengan taraf signifikan sebesar 0,000 maka $\mathrm{H}_{1}$ diterima artinya ada hubungan yang signifikan antara pengetahuan wanita usia subur tentang kanker serviks dengan minat melakukan pap smear.

Semakin baik pengetahuan responden akan tentang kanker serviks maka semakin tinggi juga minat melakukan pap smear. Pengetahuan tentang kanker serviks menjadi faktor yang penting untuk terbentuknya minat wanita usia subur melakukan pap smear.

Pengetahuan adalah merupakan hasil tahu yang terjadi setelah orang mengadakan pengindraan terhadap suatu objek tertentu. Pengindraan terhadap objek terjadi melalui panca indra seperti penglihatan, penciuman, pendengaran, perasa dan peraba dengan sendiri (Ariani, $2014: 18$ ).

Seseorang yang memiliki pengetahuan yang baik akan cenderung terus berusaha untuk menggali informasi dan pengetahuan yang dimilikinya. Ketika wanita usia subur sudah benar-benar mengetahui tentang kanker serviks dan pap smear, maka mereka akan lebih memiliki minat yang tinggi untuk merubah dirinya.

Pengetahuan hendaknya diberikan wanita usia subur melalui penyuluhan atau waktu pertemuan PKK yang diberikan oleh tenaga kesehatan maupun bidan.

Berdasarkan hasil tabulasi data jawaban kuesioner responden tentang minat melakukan pap smear diketahui bahwa minat responden akan melakukan pap smear tinggi sebanyak 26 responden $(86,67 \%)$.

Selain dari perasaan senang dan perhatian, untuk mengetahui berminat atau tidaknya seseorang terhadap suatu objek dapat dilihat dari pengetahuan yang dimilikinya (Supriatna, 2009). Oleh karena itu pengetahuan akan mempengaruhi minat seseorang.

Peran dari petugas sangat penting sebagai pendorong untuk meningkatkan pengetahuan dan lebih meningkatkan minat responden. Petugas diharapkan dapat memberikan informasi kepada responden melalui penyuluhan kesehatan sehingga responden dapat memahami tentang deteksi dini kanker serviks dengan pemeriksaan pap smear.

Mempertahankan minat yang tinggi bagi wanita usia subur. Wanita usia subur yang minatnya rendah perlu untuk ditingkatkan dan menambah wawasan lalu mengikuti acara penyuluhan-penyuluhan pada acara pertemuan di RT, dan kelompok PKK yang telah diadakan di RT 16 Kelurahan Blabak Kecamatan Pesantren Kota Kediri.

\section{SIMPULAN}

Berdasarkan analisa ada hubungan antara pengetahuan wanita usia subur tentang kanker serviks dengan minat melakukan pap smear yaitu hasil uji spearman's rank di peroleh nilai $\mathrm{p}$ value $=0,000<0,05$, maka $\mathrm{H}_{1}$ diterima. 


\section{DAFTAR PUSTAKA}

Aminati, D. 2013. Cara Bijak Menghadapi dan Mencegah Kanker Leher Rahim (Serviks). Yogyakarta: Katalog Dalam Terbitan (KDT).

Ariani, A, 2014. Aplikasi Metodologi Penelitian Kebidanan dan Kesehatan Reproduksi. Yogyakarta: Nuha Medika.

Handayani, L. et al. Menaklukkan Kanker Serviks dan Kanker Payudara dengan 3 Terapi Alami. 2012. Jakarta: PT ArgoMedia Pustaka.

Notoatmodjo, S.2012. Metodologi Penelitian Kesehatan. Jakarta: Rineka Cipta.

Nursalam,. 2011. Konsep dan Penerapan Metodologi Penelitian Ilmu Keperawatan Pedoman Skripsi, Tesis, dan Instrumen Penelitian Keperawatan. Jakarta: Salemba Medika.

Proverawati, A., Misaroh, S.2009. Menarche Menstruasi Pertama Penuh Makna. Yogyakarta: Nuha Medika.

Purwoastuti, E., Walyani, E.2015. Panduan Materi Kesehatan Reproduksi \& Keluarga Berencana. Yogyakarta: Pustaka Baru Press.

Rahayu,. 2015. Asuhan Ibu dengan Kanker Serviks. Jakarta: Salemba Medika.

Romauli, S., Vindari, A. 2012. Kesehatan Reproduksi Buat Mahasiswa Kebidanan. Yogyakarta: Nuha Medika.

Samadi, H. 2011. Yes, I Know Everything About Kanker Serviks. Jakarta: Tiga Kelana.

Savitri, A. dkk. 2015. Kupas Tuntas Kanker Payudara Leher Rahim \& Rahim. Yogyakarta: Pustaka Baru Press.
Setiadi,. 2013. Konsep dan Praktik Penulisan Riset Keperawatan. $2^{\text {nd }}$ ed. Yogyakarta: Graha Ilmu.

Slameto,. 2013. Belajar dan Faktor-faktor yang Mempengaruhi. Jakarta: Rineka Cipta.

Wawan, A., Dewi. 2010. Teori \& Pengukuran Pengetahuan, Sikap, dan Perilaku Manusia Dilengkapi Contoh Kuesioner. Yogyakarta: Nuha Medika.

Digambiro, Reza Aditya. 2015. Sel-Sel Skuamosa Antipik pada Papanicolau Smear. (online). Diakses dari : http http://drdigambiro.blogspot.co.id/2015/05/sel-selskuamosa-atipik-pada.html (Diakses pada tanggal 27 April 2017 jam 18.00).

Kartika, Annisiia. 2016. SK 3 Blok Neoplasia Ak. (Online). Diakses dari : http://docslide.net/documents/sk3-blok-neoplasiaak.html (Diakses pada tanggal 27 April 2017 jam 15.00)

Moringa, bee. 2016. Obat Herbal Kanker Serviks Ampuh Tradisional Stadium 3 dan 4. (Online). Diakses dari : http://www.bee-moringa.com/obatherbal-kanker-serviks-ampuh-tradisionalstadium-3-dan-4/ (Diakses pada tanggal 27 April 2017 jam 20.00).

Suparyanto,. 2011. Konsep Dasar Minat. (Online). Diakses dari : http://drsuparyanto.blogspot.co.id/2011/09/konsep-dasarminat.html? $\mathrm{m}=1$ (Diakses pada tanggal 12 Februari 2017 jam 21.30).

Supriatna, H. 2009. Minat Belajar. (Online). Diakses dari http://asbabulismu.blogspot.com/2009/04/minatbelajar.html. (Diakses pada tanggal 12 Februari 2017 